\title{
超音波凝固切開装置のキャビテーション発生に関する基礎的検討
}

\author{
蜂屋 弘之 ${ }^{1}$ 大屋 優 ${ }^{2}$ 山口 匡 $^{3}$ 林 秀樹 ${ }^{3}$
}

\begin{abstract}
抄 録
目的：超音波凝固切開装置は腹腔鏡手術下などで広く利用されているが，処置部分とは異なる離れた位置の組織に 損傷を与えることがあるのではないかと懸念され，その原因としてキャビテーションが指摘されている，そこで， 実際の装置を用いてブレードからのキャビテーションの発生状況について検討する. 対象と方法 : 超音波凝固切開 装置ブレードの振動分布を, レーザードプラ振動計を用いて計測すると共に, 水中観測に扔いてキャビテーション の発生状況を確認し, 八イドロホンにより水中での音圧分布を測定し, 超音波振動源から離れた位置にまで作用が 波及する可能性について検討した．結果と考察：レーザードプラ振動計によって測定したブレードの振動分布と観 察したキャビテーション気泡の発生位置の関倸から, 振動振幅の大きな領域から気泡が発生していることがわかっ た. さらに, 水中でのブレード周囲の音圧測定, 周波数解析から, キャビテーションが発生する可能性のある領域 について, 検討を行った. 気泡の観察結果と音圧測定結果は整合性があり, キャビテーションが発生し, 生体作用 を及ぼす範囲は，最大でもブレードから数 $\mathrm{mm}$ 以内であると推定された，結論：キャビテーションはブレードの ごく近傍から局所的に発生し, 音響流によって移動する可能性はあるものの, キャビテーションによる直接的作用 はブレード近傍に限定されると推測された。
\end{abstract}

\section{Verification of generated cavitation of an ultrasonically activated scalpel}

\author{
Hiroyuki HACHIYA, EJSUM ${ }^{1}$, Masaru OYA², Tadashi YAMAGUCHI, EJSUM ${ }^{3}$, Hideki HAYASHI ${ }^{3}$
}

\begin{abstract}
Purpose: Ultrasonically activated scalpels are used widely in laparoscope-assisted surgery, but there is concern that they may damage tissue at sites other than the site of the surgical procedure. Cavitation has been cited as a cause of such damage. In this paper, we examined the possibility that the cavitation effect spreads beyond the ultrasonic vibration source. Subjects and methods: We measured the vibration distribution of the blade with a laser Doppler vibrometer, and the sound pressure distribution near the blade with a hydrophone. We also observed the generation of cavitation bubbles underwater using high-speed digital video. Results and Discussion: From the relation between the vibration distribution on the blade and the observed position of bubble generation, it became obvious that cavitation bubbles are mainly generated at the large vibration amplitude region on the blade. We examined the region where cavitation bubbles might be generated from the sound pressure measurement and frequency analysis around the blade in the water. The bubble generation region showed a strong correlation with measurement results of acoustic pressure. It was estimated that bubble generation was localized to the region within several $\mathrm{mm}$ from the blade. Conclusion: Cavitation bubbles are generated locally near the blade. It is supposed that the direct effect of cavitation is limited to the vicinity of the blade.
\end{abstract}

Jpn J Med Ultrasonics 2012; 39(2) : 101-111

\section{Keywords}

ultrasonically activated scalpel, cavitation, ultrasonic therapy, laser Doppler vibrometer, bubble

\section{1.はじめに}

超音波エネルギーの医用分野への応用は, 診断応 用と治療応用に大きく分けることが出来る。診断応 用においては超音波画像診断装置が広く利用されて
いる，一方で治療応用においても，治療対象部位に 大きな超音波エネルギーを集束させ，焦域中の生体 組織を蛋白凝固点 $\left(50-70^{\circ} \mathrm{C}\right.$ 程度）以上に加熱して 凝固壊死させることにより局所的に除去する加熱凝 固療法, 衝撃波を尿路中や胆囊中の結石に集束させ

\footnotetext{
${ }^{1}$ 東京工業大学大学院理工学研究科機械制御システム専攻, ${ }^{2}$ 千葉大学大学院融合科学研究科情報科学専攻, ${ }^{3}$ 司フロンティアメディカル 工学研究開発センター

${ }^{1}$ Graduate School of Engineering, Tokyo Institute of Technology, 2-12-1 Ookayama, Meguro-ku, Tokyo 152-8550, Japan, ${ }^{2}$ Graduate School of Advanced Integration Science, ${ }^{3}$ Research Center for Frontier Medical Engineering, Chiba University, 1-33 Yayoi, Inage, Chiba 263-8522, Japan
}

Received on October 2, 2009; Revision accepted on November 7, 2011 


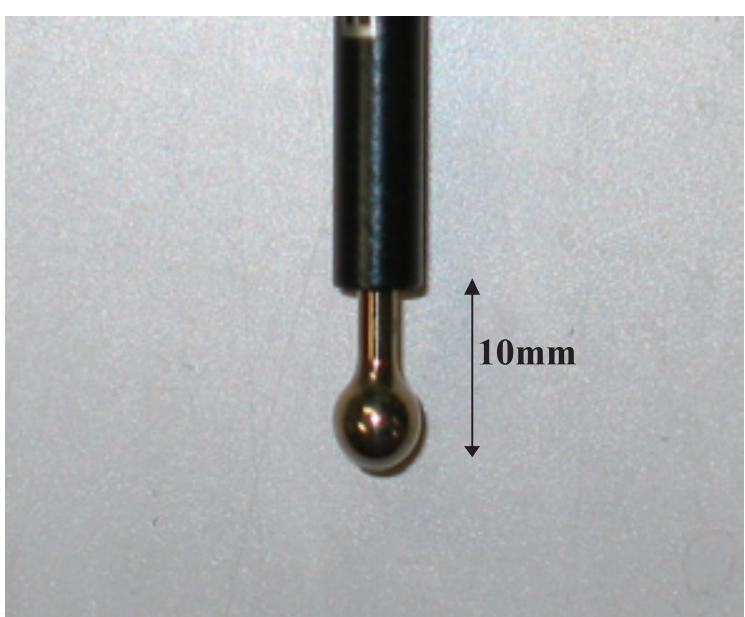

Fig. 1 球状ブレード（HBC05）

破砕を行う体外衝撃波砕石術，また腹腔鏡手術下な どで広く利用されている超音波振動によって人体組 織の凝固・切開を同時に行うことが出来る超音波凝 固切開装置 ${ }^{1)}$ な゙盛んに使われている.

超音波凝固切開装置に扔いては，処置を行ってい る部位から離れた位置の組織に損傷を与えることが あるのではないかと懸念されている，周囲組織の損 傷の機序として, 先端のブレードからのキャビテー ションに伴う効果が指摘されているが2), 工学的な 検討は不十分で，正確でない記述も散見される。本 論文では実際の装置に挍いてブレードの振動分布を， レーザードプラ振動計を用いて計測すると共に，水 中観測において生体組織の損傷につながる可能性の あるキャビテーションの発生状況をハイスピード ディジタルムービーで確認し, さらにハイドロホン により水中での音波伝搬の状況を検証し, 超音波振 動源から離れた位置にまで作用が波及する可能性に ついて検討した結果を述べる.

\section{2. 対象と方法}

\section{1 超音波凝固切開装置}

超音波凝固切開装置は, 超音波振動を利用し, 人 体組織の凝固切開を同時に行うことが出来る手術器 具で, 本研究で用いた超音波凝固切開装置は, ジョ ンソン・アンド・ジョンソン社製，ハーモニック・ スカルペル II を使用した。装置は, ジェネレーター, ハンドピース，フットスイッチ，ブレードから構成 され,フットスイッチの操作により, ジェネレーター から電気エネルギーが発生し, ハンドピースに内蔵 されたアコースティックトランスデューサによって

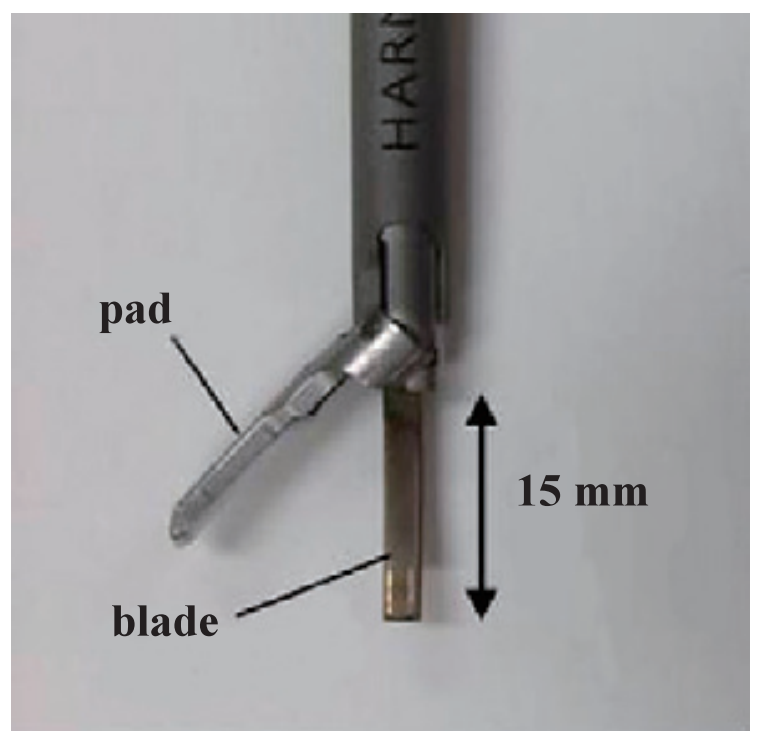

Fig. 2 曲線型ブレード（Harmonic ACE：ACE36P）

超音波振動の機械的エネルギーに変換され，ブレー ドに伝わる，先端のアクティブブレードは， 55.5 $\mathrm{kHz}$ の周波数で振動する仕様になっており, この振 動によって組織に対して正確な切開と比較的低温で の凝固作用をもたらす装置である ${ }^{3)}$. 出力設定は最 小出力（設定 1） から最大出力（設定 5）まで 5 段 階に変化させることが出来る.

切開は, 振動するブレードが局所的に組織を弾性 限界以上に伸展させることを繰り返すことで機械的 に行われ，ブレードへ加える術者の手の圧力により 程度がコントロール出来る。 また, 凝固はブレード の振動による摩擦熱が生体組織中の蛋白質を熱変性 させることによって血管などの管腔状の構造物が接 合されて起こる。

ブレードは, Fig. 1 に示す球形ブレード（HBC05） と Fig. 2 に示す曲線型のブレード（ACE36P）を使 用した．曲線型のブレードはいずれの実験において も,ティッシュパッドを開いた状態で, アクティベー トを行った．球形ブレードは組織に対してブレード を圧迫させることで切開することができ, 平坦な部 分を圧迫すれば凝固も行うことが出来る. 曲線型の ブレードは高速で振動するアクティブブレード部分 とパット部分とで組織を把持でき, 凝固・切開を同 時に行うことが出来る.

\section{2 振動分布測定}

生体組織に接触するブレード部分では実際にどの ような振動が励起されているのかを知るために, 空 中に扔いて装置を作動させ，スキャニングレーザー 


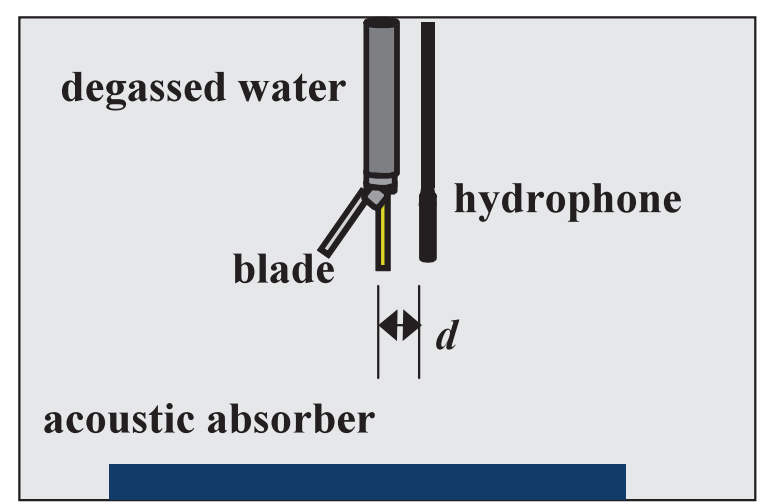

Fig. 3 音圧計測の状況

ドプラ振動計（Polytec, PVS-400）によって，その 振動分布の測定を行った．振動分布を測定するため に，通常の使用よりも長時間連続的に振動させるこ とと，空中で無負荷の状態となるため，ブレードが 過度に振動して通常の振動状態から変化しないよう に，装置の出力設定を最小（設定 1）として測定を 行った.

\section{3 キャビテーション気泡の発生状況観察}

ブレードを実際に脱気水中において作動させ，ど のような方向にキャビテーションが発生するのか実 験を行った。超音波凝固切開装置におけるキャビ テーション気泡の発生を確認するために，暗室にお いて脱気水中で装置を作動させ，一方向より光を照 射し, 球型・曲線型の 2 種類のブレード近傍におけ るキャビテーション気泡の発生状況をハイスピード ディジタルカメラ（カシオ，EX-F1）を用いて 1,200 fps（frame per second）で撮影した. 1,200 fps のハ イスピード動画では撮影画素が $336 \times 96$ ピクセル に制限される。ブレード周囲の水槽壁には吸音材を 置き，壁からの反射が小さくなるようにした，出力 設定を変化させながら観察を行ったが，主に，臨床 での使用頻度が最も高いと思われる出力最大の設定 （設定 5）を中心に装置を動作させ検討した.

\section{4 水中音圧波形の測定}

脱気水中で超音波凝固切開装置を作動させ, 八イ ドロホン（システムインテック，SH200K）により 水中に放射される音波を受波した。 ハイドロホンは 円筒型で，周波数带域は $20 \mathrm{~Hz}-200 \mathrm{kHz}$ であり， 直径 $10 \mathrm{~mm}$ である. Fig. 3 に計測状況を示す．八 イドロホンは, ブレードの直近に設置し，最大音圧 が計測されるように高さを調整した。出力設定を変 化させ計測を行い，またブレードとハイドロホンま

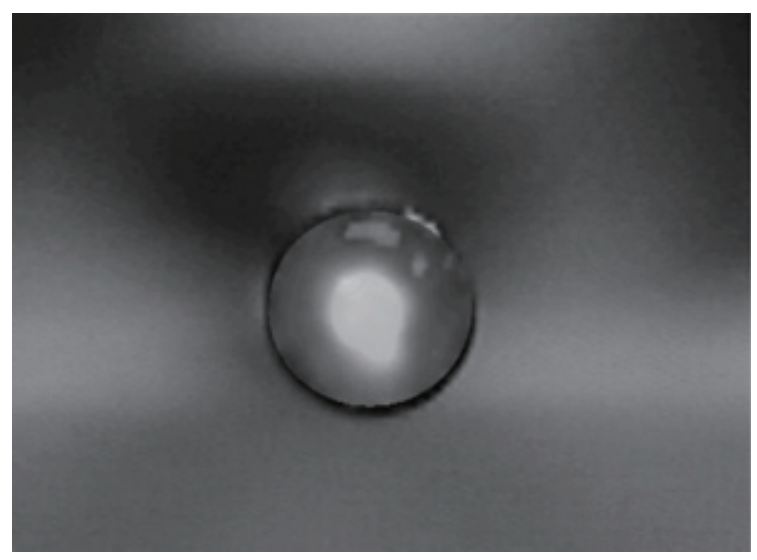

Fig. 4 球状ブレードの振動速度分布

での距離 $d$ を変化させて計測を行った。計測はそれ ぞれの設定で 10 回行い，音圧の平均と標準偏差を 求めた。

\section{3. 結果}

\section{1 振動分布測定結果}

Fig. 4 にスキャンニングレーザードプラ振動計で 測定した球形ブレードの振動速度分布を示す．球形 ブレード部の円の部分が測定領域であり，黒から白 になるにつれて振動速度が大きいことを示す．測定 しているレーザービームの方向の速度成分が計測さ れているため, 中心の速度が大きく球周囲の速度が 小さな值となっている. Fig. 5 に球形ブレード中央 の振動速度分布を示す．実線が測定值であり，点線 は球全体がほぼ一様の振幅で呼吸振動しているとし た時の測定ビーム方向の振動速度成分を計算により 求めた結果である。測定された振動速度は，半径方 向の速度に換算するとほぼ等しい振動速度となり， 球全体がほぼ一様の振幅で呼吸振動していることが 確認出来る．振動速度 $v$ の最大值は約 $20 \mathrm{~mm} / \mathrm{s}$ であ $\eta$, 振動変位 $a$ との関係 $v=\omega a （ \omega$ ：角周波数）を 用いて振幅に換算すると，ブレード表面は半径方向 に最大振幅抒よそ $0.06 \mu \mathrm{m}$ で振動している.

Fig. 6 に曲線型ブレードの振動速度分布の測定結 果を示す。ブレードの部分が測定領域であり，黒か ら白になるにつれて振動速度が大きいことを示す。 黒い部分は振動速度が 0 となっている部分である。 この測定結果はある時刻の結果であるが，破線で示 した振動速度がほぼ 0 の部分は，他の時間でも振動 して抢らず，振動の節となっている。破線で示した 振動速度 0 の境界の左右の矢印方向に速度が大きく 


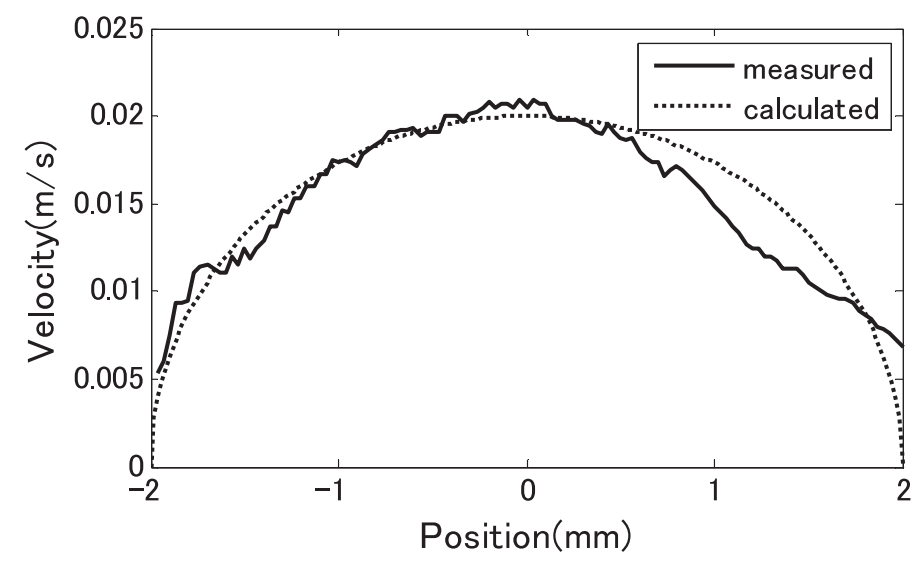

Fig. 5 球状ブレードの中央の振動速度分布

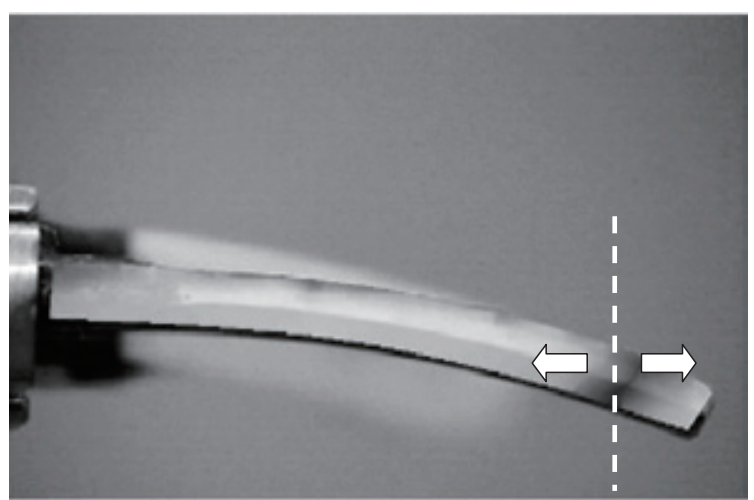

Fig. 6 曲線型ブレードの振動速度分布

なっているが，位相は境界の左右で $180^{\circ}$ 異なって おり，逆相で振動している。 この様子を Fig. 7 に 示す. Fig. 7 の実線と破線は, Fig. 6 で示されたブ レード中央の瞬時振動速度を示したもので，実線と 破線では時間が半周期異なっている. 振動速度が 0 となる振動の節の部分の左右で振動速度の符号が逆 転していることがわかる. Fig. 6,7 から,このブレー ドの側面はたわみ振動していることがわかる.

Fig. 7 に示した二つの時刻の結果が振動速度の絶対 值が最大となる時のもので, 振動速度 vの最大值は 約 $50 \mathrm{~mm} / \mathrm{s}$ であり，振幅に換算すると，ブレード 表面は測定ビーム方向に最大振幅およそ $0.15 \mu \mathrm{m}$ で振動している。

\section{2 キャビテーション気泡の発生状況}

Fig. 8 a-c に脱気水中で, 出力を変化させ振動さ せた球形ブレード近傍のキャビテーション発生状況 を示す.（a）が 5 段階の出力設定の中間の出力設定 （設定 3）で，（b）がそれより大きい設定 4, （c）が 最大出力（設定 5）の時の結果である. 球型ブレー ドにおいて, 出力設定が高くなるにつれてキャビテー
ション気泡の発生量が増加することが観察された。 同じ出力設定でも, キャビテーションの発生状況 は時間と共に変化する. Fig. 9 a-d に脱気水中で最 大出力設定で振動する球型ブレード近傍のキャビ テーション発生状況の例を示す. 同じ出力設定でも Fig. 9 a-d に示すように, 様々な気泡発生パターン が観測された。気泡発生方向は，球部分の上部と下 部付近で多く発生し, 不規則に発生位置が移動する ことが観察された. 振動している球部分が無負荷状 態では, ほぼ一様な振動分布のため, 気泡を発生し 易い負音圧の大きな領域が特定の場所でなく複数分 布しているため, キャビテーション気泡の発生位置 が, 不規則に変化しているものと考えられる. 気泡 の発生と同時に音響流が観測され，球表面から離れ た位置で観測される気泡は, 球表面から発生した気 泡が, 音響流に流されて, 遠方に移動したものと思 われる. Fig. 9 d (矢印) で示した部分のように球 状ブレード表面から離れた位置で気泡が発生してい るようにも見えるが, 気泡が視認出来るのは最大で も数秒以下の短い時間である. Fig. 10 に球状ブレー 


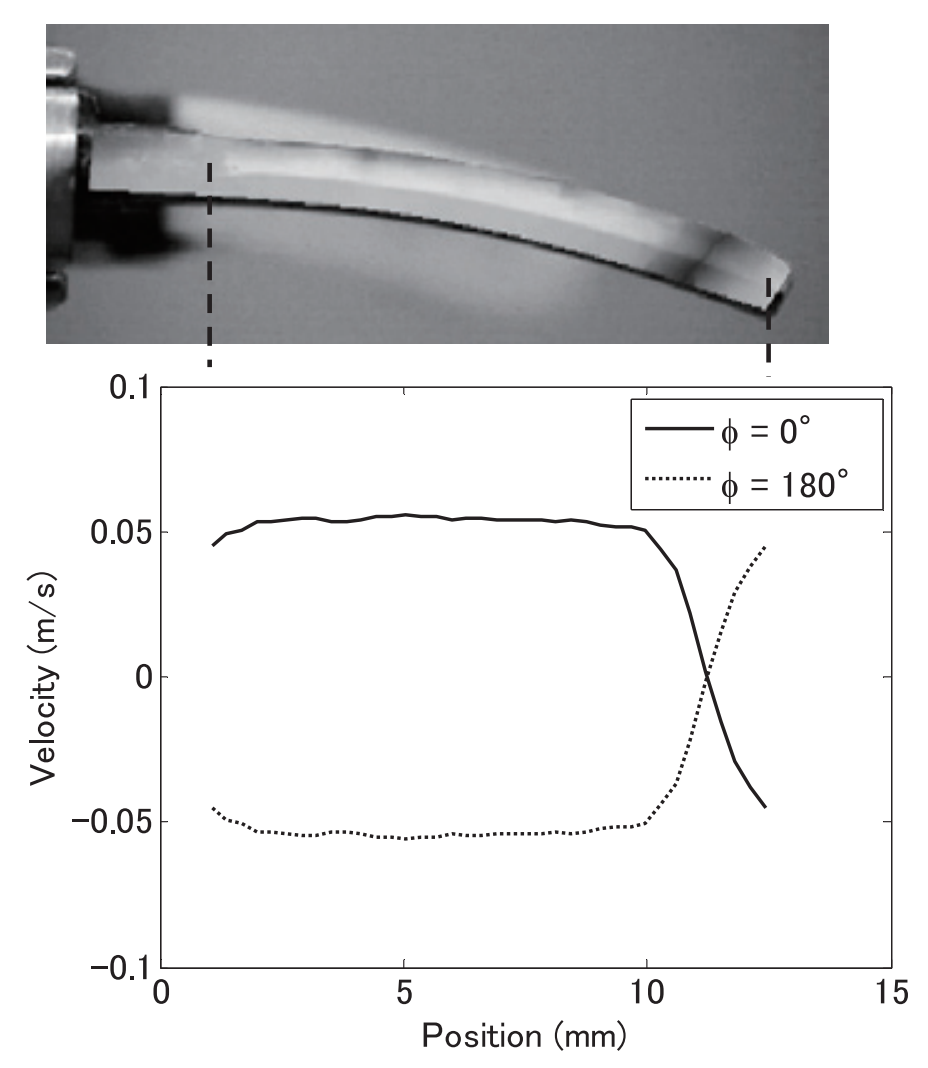

Fig. 7 曲線型ブレード中央の振動速度分布
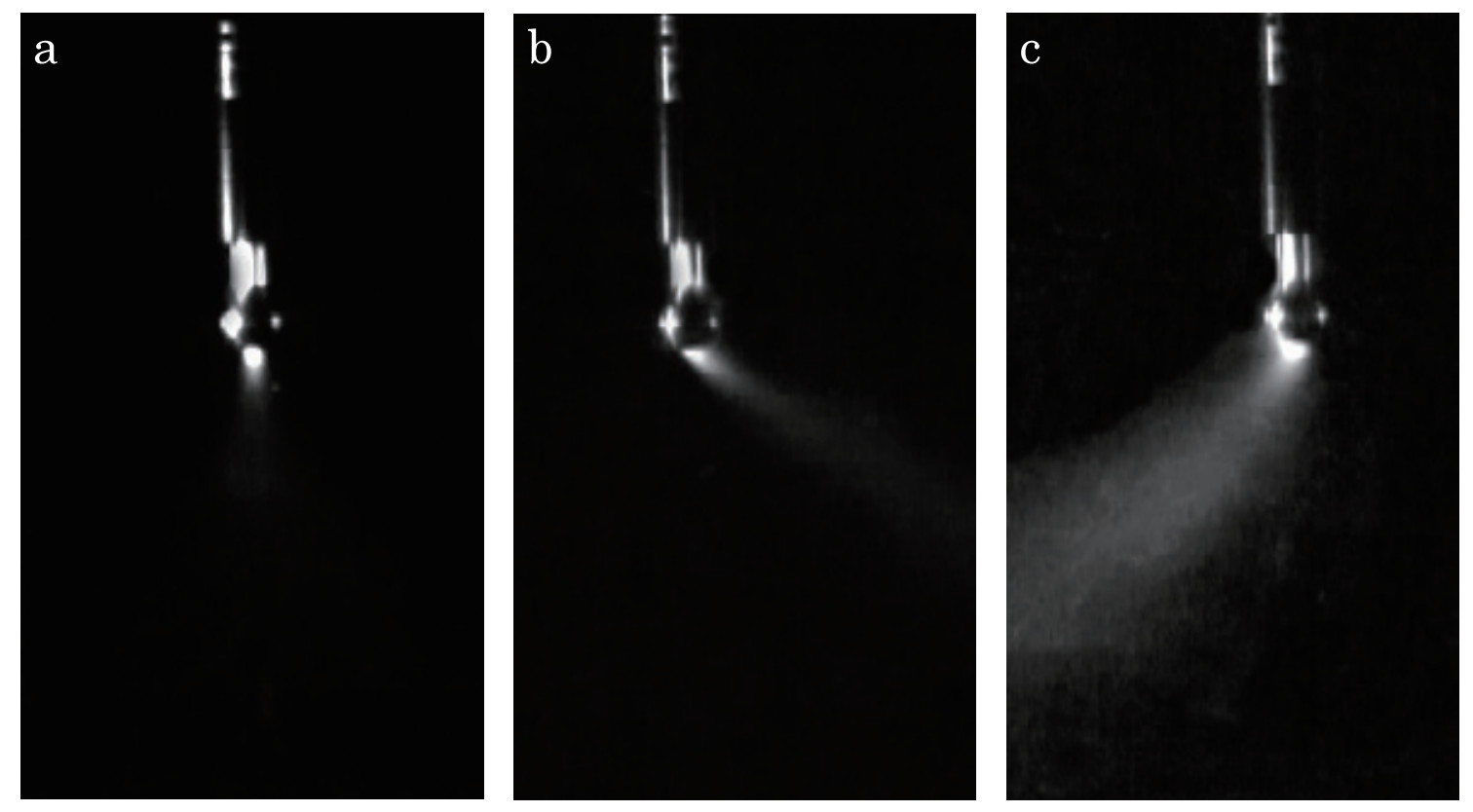

Fig. 8 球状ブレードからの気泡発生状況と出力設定の関係.（a）出力設定 3,（b）出力設定 4, (c) 出力設 定 5

ド表面から離れた位置での気泡の発生と消滅の時間 経過を示す．矢印で示す領域に,ブレード表面から 気泡が供給されている時点を $0 \mathrm{~ms}$ とすると, $3 \mathrm{~ms}$ あたりからブレード表面からの気泡の放出方向が変 化し，矢印で示す領域付近には，ブレード表面から
の気泡供給はなくなるが，それまでに放出されてい た気泡が漂い始める。この気泡が，9-15 ms あた りまでの時間に帯状に集まり, 気泡群を形成してい

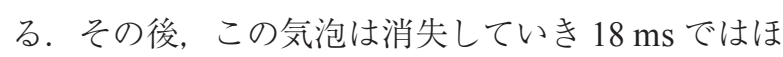
ぼ視認出来なくなる。このように, ブレード表面か 


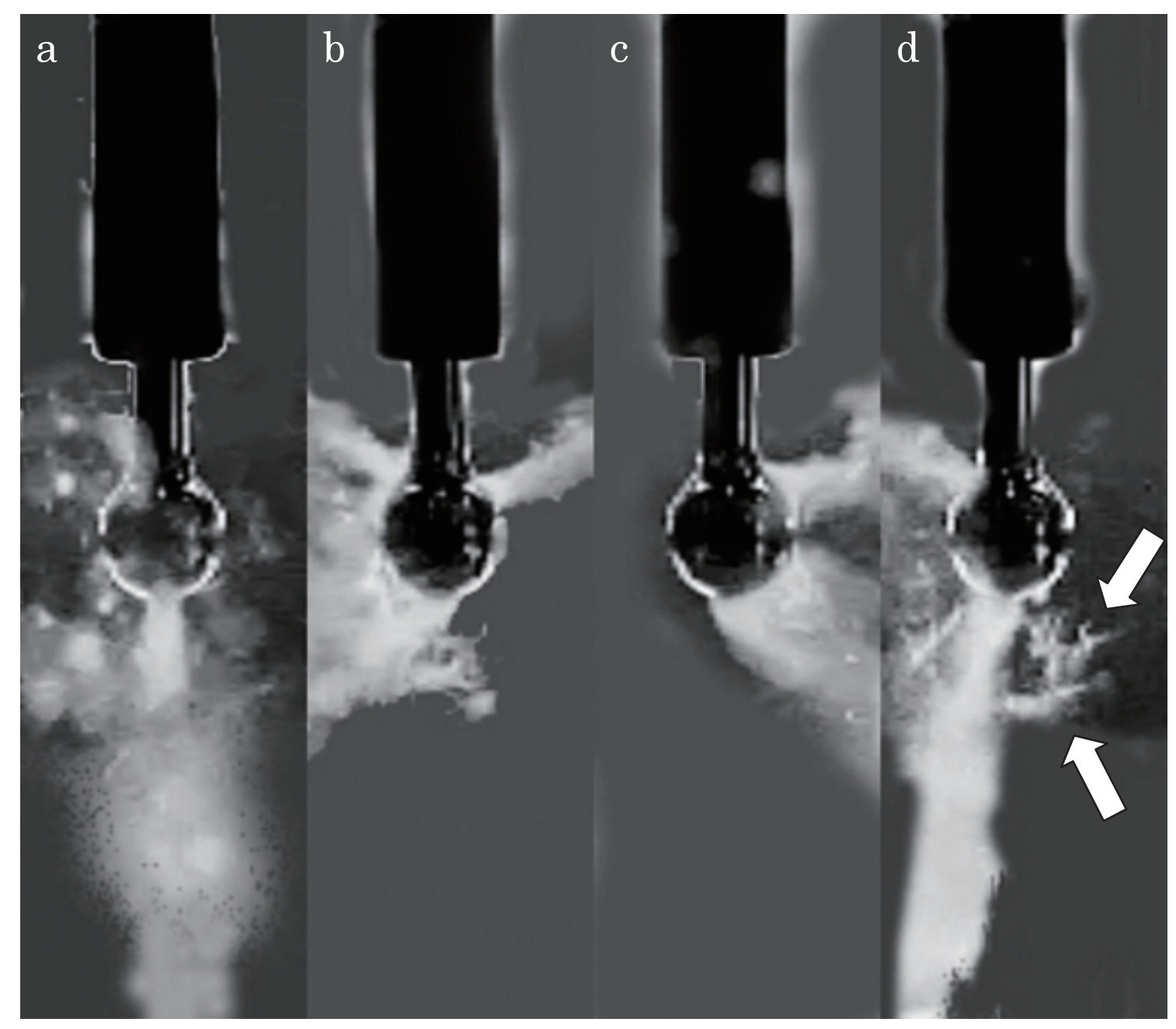

Fig. 9 最大出力設定時の球状ブレードからの気泡発生状況

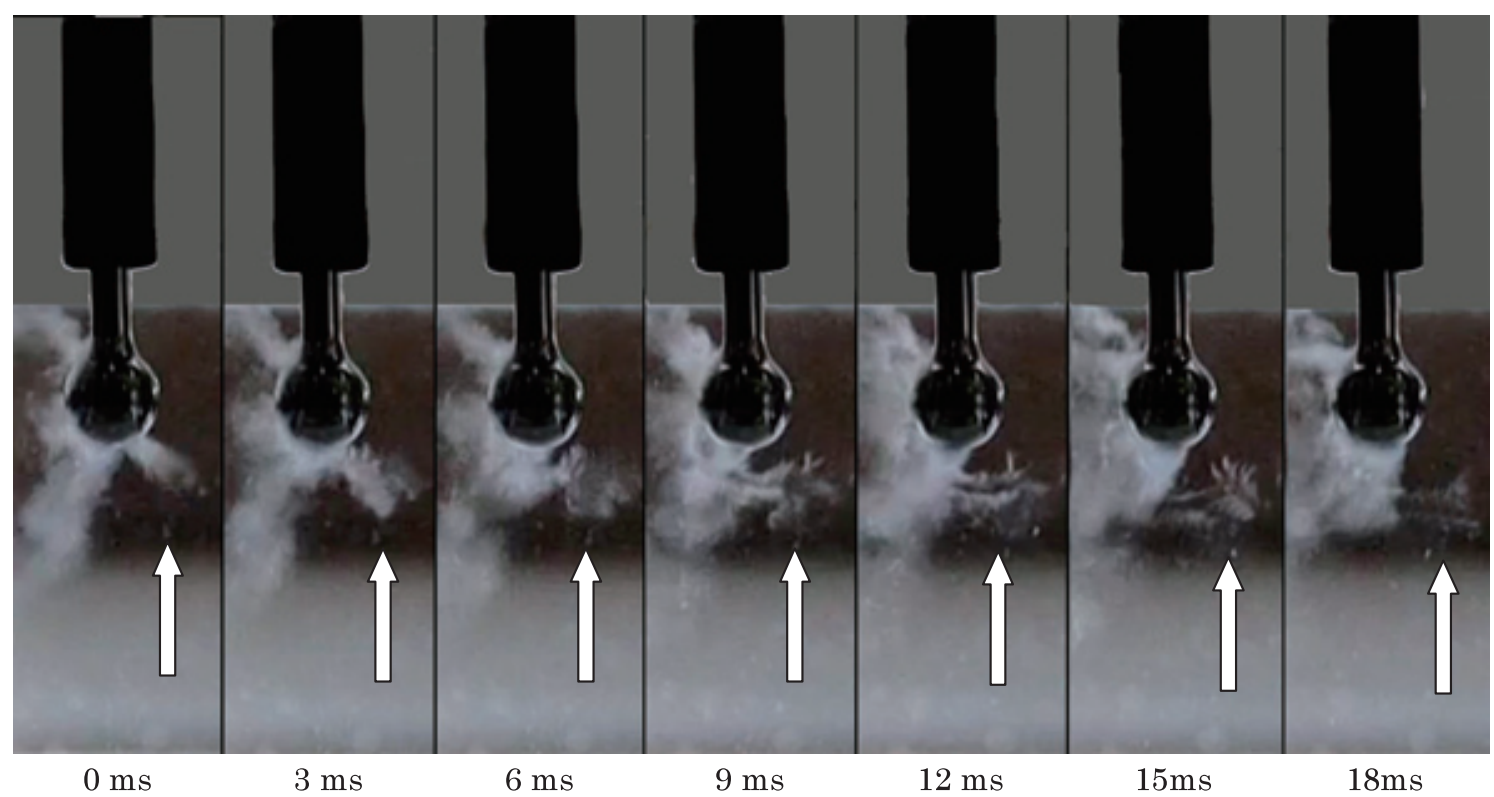

Fig. 10 球状ブレードからの気泡発生の時間経過 


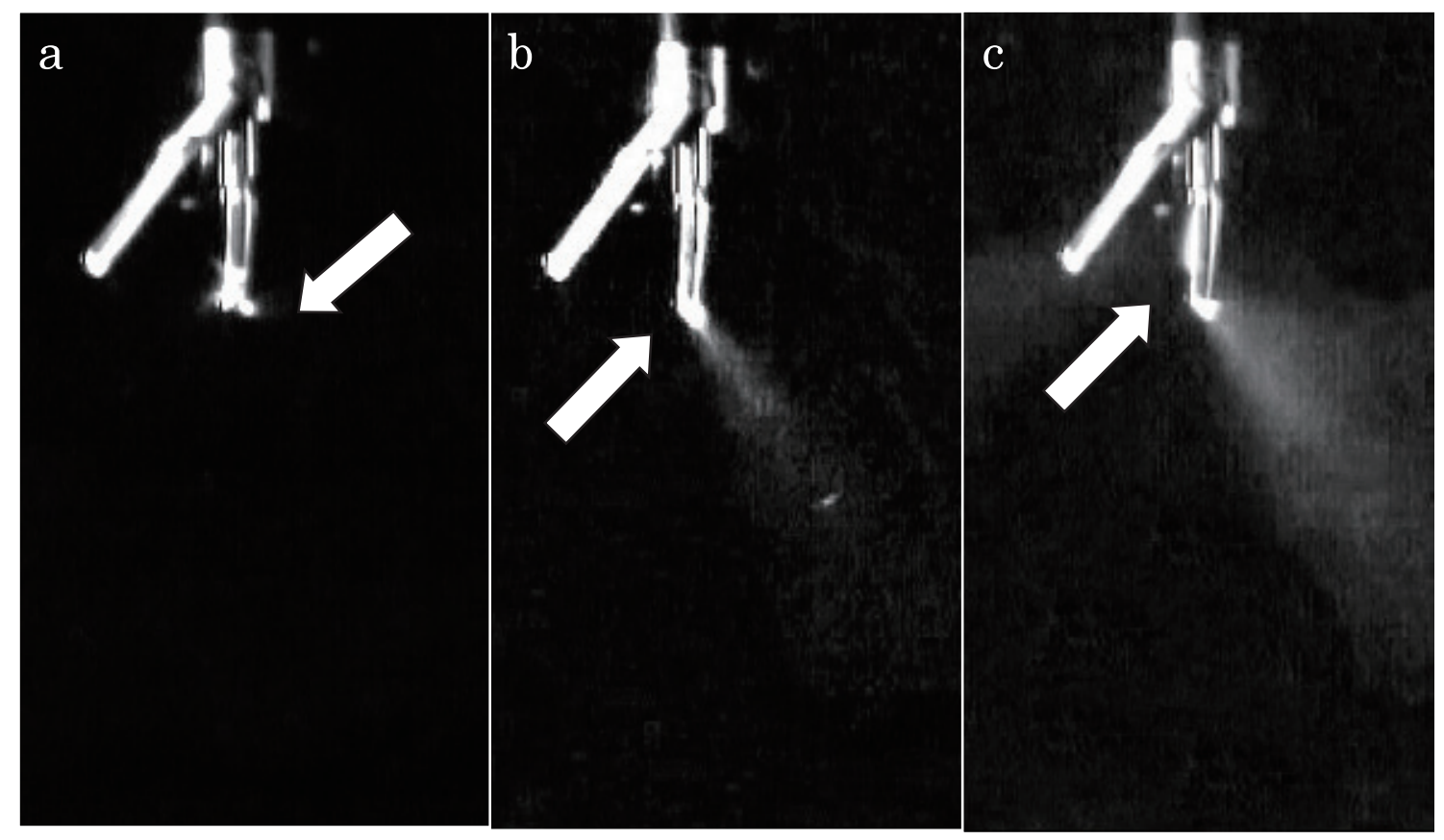

Fig. 11 曲線型ブレードからの気泡発生状況と出力設定の関係.（a）出力設定 3,（b）出力設定 4, (c) 出 力設定 5

ら離れた位置の気泡は, 前後のフレームを連続的に 観察すると表面付近から発生し, その後水中を漂っ ている気泡が一時的に集まっていると思われる。さ らに, 球表面から離れた位置に孤立して気泡が観察 されるのはごくわずかの時間で, ほとんどの気泡は 球ブレード表面近傍のキャビテーションで発生し,

音響流で拡散されたものである。

Fig. 11 a-cに脱気水中で, 出力を変化させ振動さ せた曲線型ブレード近傍のキャビテーション発生状 況を示す.（a）が5 段階の出力設定の中間の出力設 定（設定 3）で，（b）がそれより大きい設定 4，(c) が最大出力（設定 5) のときの結果である. 曲線型 ブレードに提いても出力設定が高くなるにつれてキャ ビテーション気泡の発生量が増加することが観察さ れた。

Fig. 12 a-d に最大出力設定（設定 5）における異 なる時間での曲線型ブレード近傍のキャビテーショ ン発生状況を示す. 同じ出力設定でも, キャビテー ションの発生状況は時間と共に変化しているが, 発 生方向は Fig. 12 a-c $の$ 上矢印に示すように主にブ レード先端の角から安定して発生していることが観 察された。また，左矢印で示されるブレードの振動 速度の大きかった部分からも量は少ないものの, 継 続的に発生していることが観察された。このキャビ テーション気泡の発生位置は, 3.1 節で示したブレー
ド先端の振動分布と対応していると考えられる。ま た，振動速度が 0 の部分には, 周囲で発生した気泡 が補足されることがあり，Fig. $12 \mathrm{~d}$ の矢印のよう に振動の節に気泡が带状に集まる状況が観察出来る 時がある.曲線型ブレードにおいてもキャビテーショ ンによる気泡の発生はブレード直近に限定され, 音 響流の流れに乗って気泡が移動していると考えられ る.

\section{3 音圧波形解析}

Fig. 13 a - 15 a に，最大出力設定（設定 5）の時 の曲線型ブレード直近の水中に扔ける音圧測定波形 を, Fig. 13 b - 15 b にその周波数解析結果を示す. ハイドロホンとブレードまでの距離 $d$ は $1 \mathrm{~mm}$ (Fig. 13)， $5 \mathrm{~mm}$ (Fig. 14), $20 \mathrm{~mm}$ (Fig. 15) であ る. 周波数解析結果の縦軸はそれぞれの周波数成分 の音圧実効值である。周波数解析結果から主な周波 数成分として, 超音波凝固切開装置の発振周波数で ある $55.5 \mathrm{kHz}$ の発生が確認出来る。ささらに, 基本 周波数の二倍の周波数の第二次高調波の発生が確認 出来了. $d=1 \mathrm{~mm}$ の Fig. $13 \mathbf{b}$ では第二次高調波が 基本波成分の $30 \%$ 程度の音圧となり，Fig. 13 a の 音圧波形も非対称となる. $d=20 \mathrm{~mm} の$ Fig. 15 b においては第二次高調波の発生はほとんどなくなり,

Fig. 15 a の音圧波形も歪みは確認出来るものの正 負対称となっている. 


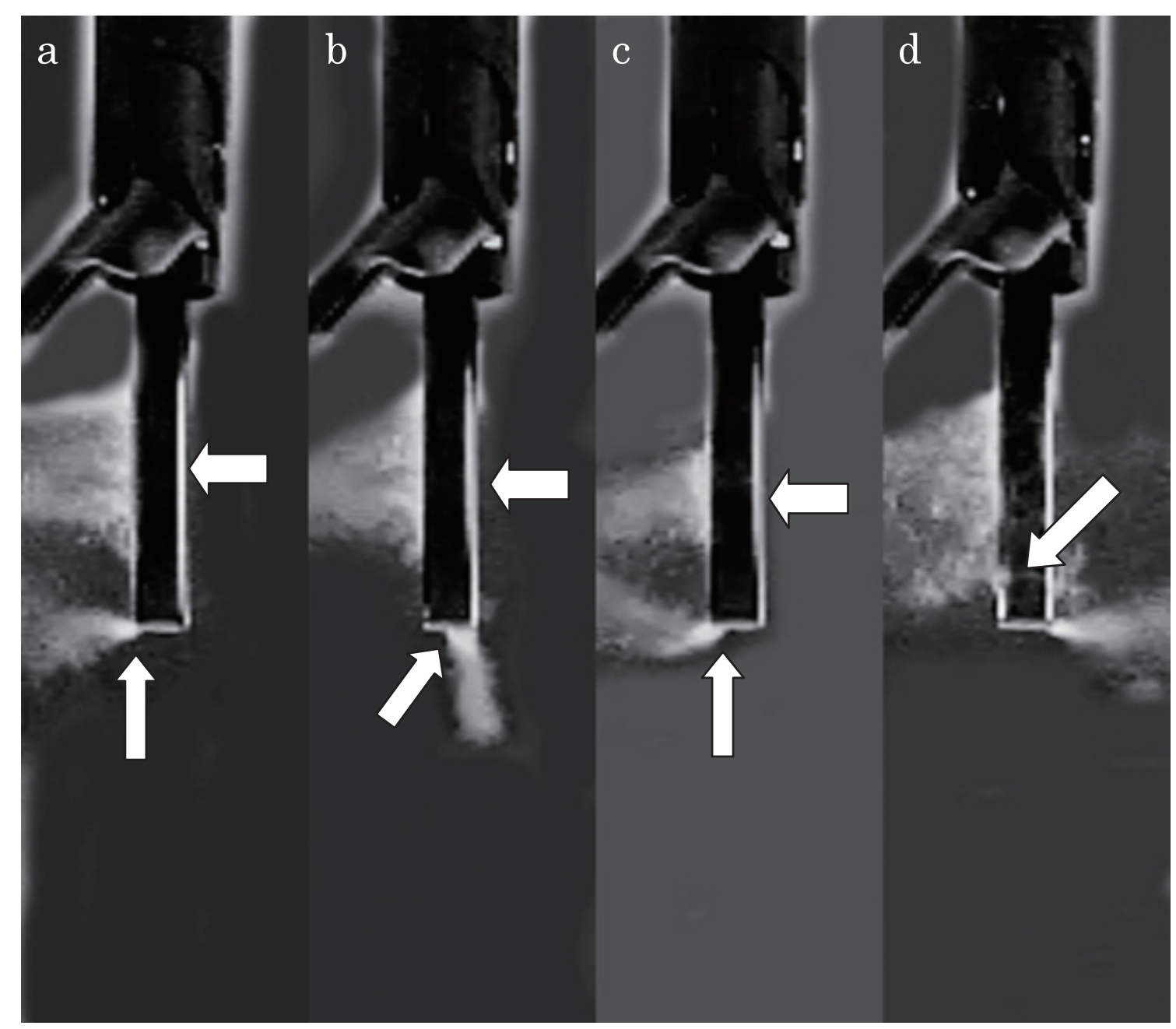

Fig. 12 最大出力設定時の曲線型ブレードからの気泡発生状況

Fig. 16 に出力設定を最低出力（設定 1）から最 大出力（設定 5）に変化させた時の曲線型ブレード 直近の水中に拟音圧波形から求めた正圧ピーク の最大值 (実線) と絶対值が最大となる負圧ピーク (点線）の関係を示す. 出力設定が最小の時（設定 1) は, 正圧と負圧の絶対值がほぼ等しいが, その後, 正圧の増加に比べて, 負圧の絶対值の増加は緩やか である。

Fig. 17 にFig. 13 b-15 b で求めた周波数成分の 基本波 (実線) と第二次高調波 (点線) の実効值振 幅と距離 $d$ の関係を示す. 各距離で測定は 10 回行 われているので, その平均と標準偏差をエラーバー で表示している. 破線はハイドロホン表面からブレー ド表面までの距離 $d(\mathrm{~mm})$ を用いて, ハイドロホ ン中心からブレード中心までの距離 $d+6 \mathrm{~mm}$ に反 比例して音圧 $p(\mathrm{kPa})$ が減少するとして描いた基本 波成分の理論曲線であり,

$$
p(d)=A /(d+6)
$$

である。ここで $A(\mathrm{kPa} \cdot \mathrm{mm})$ は基本波成分の測定 值に適合するように定められる定数であり, ここで は $A=300$ とした.

Fig. 18 に Fig. 13 b-15 b の音圧波形から求めら れた正圧ピークの最大值 (実線) と絶対值が最大と なる負圧ピーク (点線) と距離 $d$ の関係を示す. 破 線は Fig. 17 と同様にハイドロホン中心からブレー ド中心までの距離に反比例して音圧が減少している として描いた理論曲線である。

\section{4. 考 察 $^{4-8)}$}

Fig. 17, 18 の距離に対する音圧分布から, 曲線ブ レード直近の非線形に基づく効果を除けば，ブレー ドから発生した音波は球面状に拡散していると考え られる。これは音波の放射に関係する振動速度の大 きなブレード上の音響放射面が，ブレードから発生 する音波の水中での波長約 $30 \mathrm{~mm}$ から比べても十 分小さいことからも妥当である. 平面波の音の強さ 

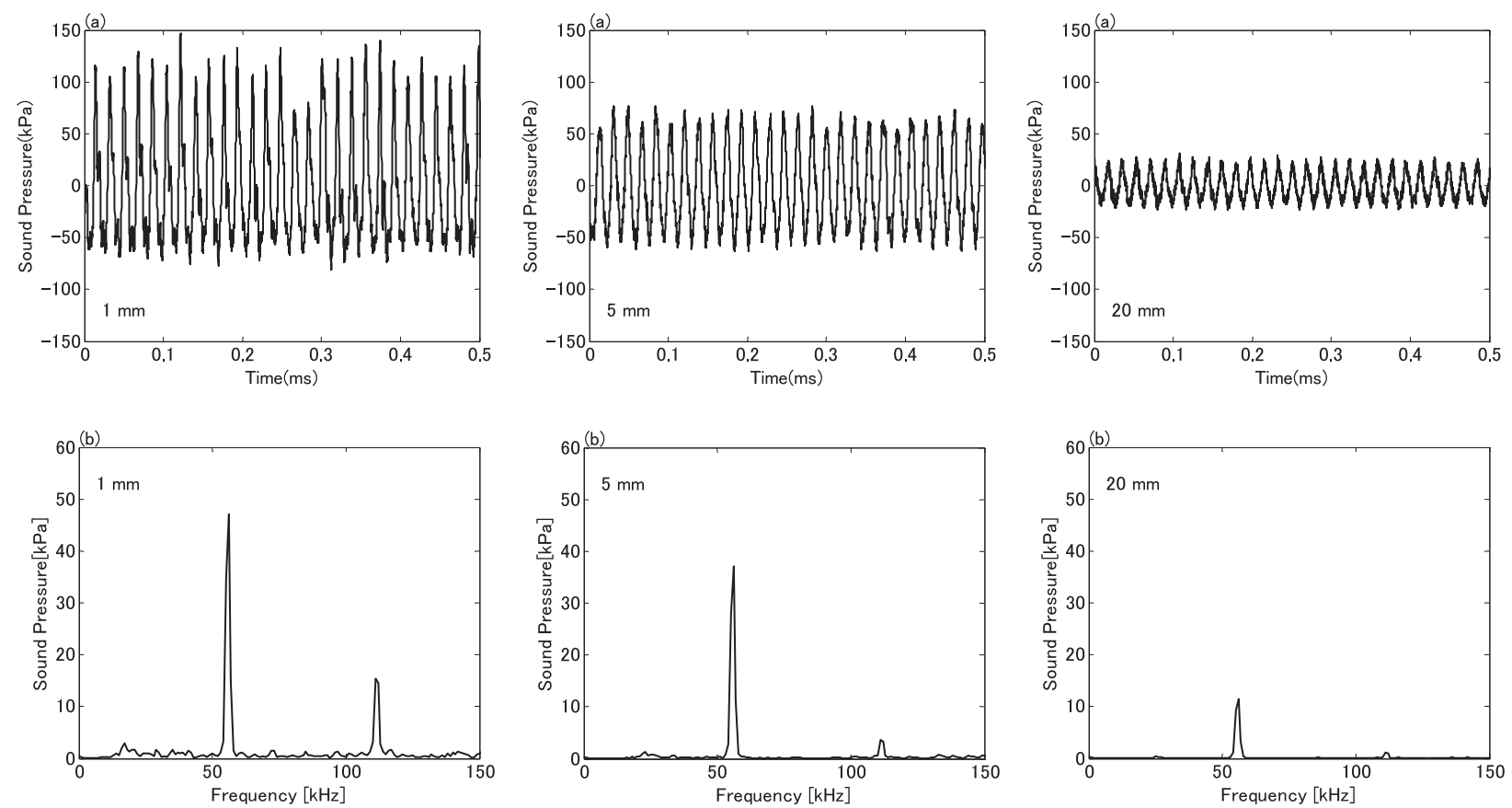

Fig. 13 曲線型ブレードから $1 \mathrm{~mm}$ の位置での放射音波の音 圧（a）と周波数成分（b)

Fig. 14 曲線型ブレードから $5 \mathrm{~mm}$ の位置での放射音波の音 圧（a）と周波数成分（b)
Fig. 15 曲線型ブレードから 20 $\mathrm{mm}$ の位置での放射音波 の音圧（a）と周波数成分 (b)

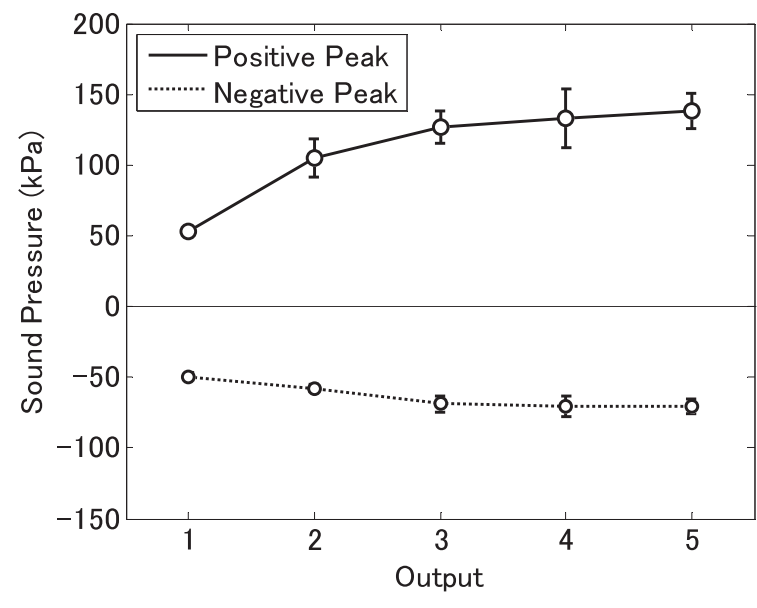

Fig. 16 出力設定を変化させた時の正圧ピークと負 圧ピークの最大值

$I\left(\mathrm{~W} / \mathrm{cm}^{2}\right)$ は, 音圧 $p$ と固有音響インピーダンス $z=\rho \mathrm{c}$ を用いて

$$
I=p^{2} / \rho \mathrm{c}
$$

で求められる。音波が球面波として拡散していると, 平面波の場合と異なり, 音圧と粒子速度の複素比, 比音響インピーダンスは球中心からの距離に依存す ることになるが，球中心から波長程度離れれば，ほ ぼ平面波の比音響インピーダンスである固有音響イ ンピーダンス $\rho \mathrm{c}$ で近似出来る. 球中心に近いとこ

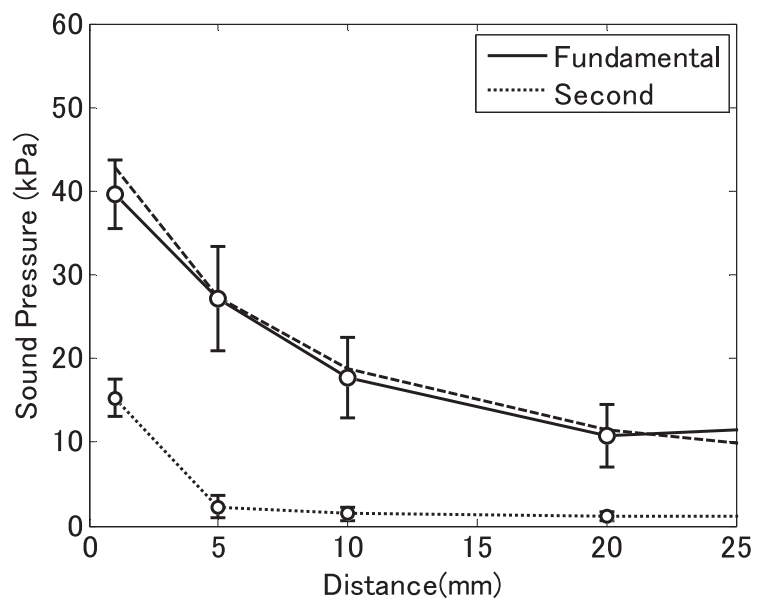

Fig. 17 ブレードからの距離と基本波と第二次高調 波成分の関係

ろでは比音響インピーダンス $z_{\mathrm{t}}$ の絶対值は固有音

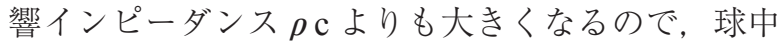
心に近いところでは，(2) 式を用いて音の強さを計 算すれば，音の強さは過大に評価されることになり 安全性を考える上では好都合である。したがって， ここでは球面波として拡散しているが, 音の強さは 距離に関わらず（2）式を用いて評価することにする. キャビテーションの発生する圧力閾值, すなわち キャビテーション閯值は, 溶存気体, 液体中に微量 


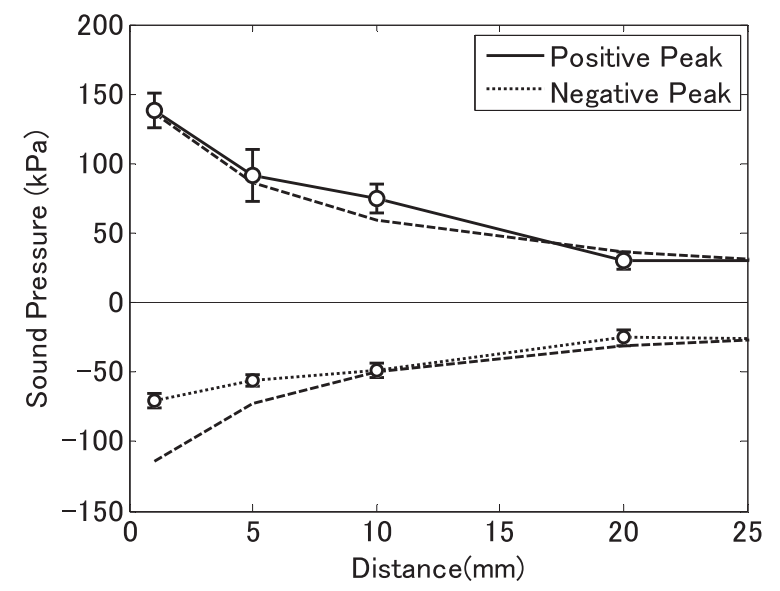

Fig. 18 ブレードからの距離と正圧ピークと負圧 ピークの最大值の関係

に存在する固体表面に捕縛されている気体などキャ ビテーション核の存在に依存するので, 単純ではな いが，空気で飽和した水のキャビテーション䦨值の 結果などを参考に， $50 \mathrm{kHz}$ において負圧力ピーク 值 $50 \mathrm{kPa}$ ，音の強さ $0.1 \mathrm{~W} / \mathrm{cm}^{2}$ 以下であれば，キャ ビテーション気泡の発生はほとんどない".

Fig. 18 の測定結果から, 距離の大きなところでは, 負音圧の絶対值と距離は反比例の関係にあるものの, ブレード直近では非線形性のため, $1 / d$ で計算さ れる值ほどの負音圧にはならない。測定結果から， 距離 $1 \mathrm{~mm}$ のところでの負圧力の絶対值の最大は変 動を考慮して $100 \mathrm{kPa}$ と見積もれる。超音波診断装 置で用いられる $\mathrm{MHz}$ 带の周波数のパルス超音波の 生体作用の程度を示す指標として MI 值があるが, 数 $10 \mathrm{kHz}$ 帯の連続波超音波の凝固切開装置でも目 安として MI 值を計算すると, 最大負音圧 $100 \mathrm{kPa}$, 周波数 $55.5 \mathrm{kHz}$ として 0.43 となる.

Fig. 18 の音圧測定結果からブレードから $10 \mathrm{~mm}$ 離れた地点ではキャビテーション気泡の発生はない と推定される。音波が拡散する状況では音源に近い ほどキャビテーションの発生確率は高く,ひとたび, 気泡が発生するとそれより遠方の音圧は急速に減衰 するので, 波長に比べ小さな音響面を持ち, 球面波 状に音波が拡散する場合には，音源直近以外でキャ ビテーション気泡が発生することは難しいと思われ る.また, 振動面直近で, 音圧がキャビテーション 閾值を超えて気泡が発生すると, 音源の放射抵抗が 低下し音波の放射効率を下げ，キャビテーション閾 值を超える振幅の音波を連続放射するのは不安定に なりがちである. Fig. 12 a-d の観測結果では, ブレー
ドの振動速度の大きな端面の角から, 比較的安定に 活発なキャビテーション気泡が生成されているもの の, 発生位置は時々変化する。 これは, 上記の検討 結果と整合している。ただし, キャビテーションが 最も多く発生している箇所は, ブレードの治療対象 部位に接触する箇所ではないことに注意する必要は ある. 周波数 $55.5 \mathrm{kHz}$ に共振する気泡半径は 58.7 $\mu \mathrm{m}$ 程度であり, この径付近の気泡の作用が一番大 きいと思われる，八イスピードディジタルムービー では 1 ピクセルが $130 \mu \mathrm{m}$ 程度の視野となっており， 共振気泡個々の詳細な観測には不足であるが, 気泡 群の補足には支障がない.

ハイスピードディジタルカメラにより観察したキャ ビテーションの発生状況は, 波長に比べ小さな音響 放射面を持つブレードでは, 音源直近の限られた領 域からのみキャビテーション気泡が生成されている ことが示されている.しかし, 同時に発生している 音響流により, 発生気泡は遠方まで移動しているが, 遠方ではすでに音圧が距離に反比例して減少してい るので, キャビテーション気泡を圧壊させ, 機械的, 化学的作用を生じさせることはない.これらの結果 は, 波長より小さな音響放射面をもつ超音波治療機 器全体に関連する検討結果であり，一般化していく ことが望まれる。

以上より, 一般的な超音波凝固切開装置の最大出 カでのキャビテーションによる直接的な作用はブ レード直近の数 $\mathrm{mm}$ 以内の範囲内に限定されると 推測される. そのため, 実際の使用状況も考慮する と, 生体組織にブレードが接触する程度の距離でな ければキャビテーションによる影響は少ないと思わ れる。

橋本らは, 本実験に関連し, 生理食塩水中でブタ 小腸と超音波凝固切開装置のブレード先端との距離 を様々に変化させてアクティベートし, 組織の変化 を組織学的に観察したところ，0.3 mm 以上離した 状態では異常所見を認めないことを報告した ${ }^{10)}$. こ れは, 本報告で推測された結果と一致している.

ただし，本報告では，ブレード直近の音響化学的 な作用により生成された活性化物質などの広がりに よる効果は不明であり, 検討を進める必要がある。 また，熱的作用についても未検討であり，これも今 後の課題である. 


\section{5. 結}

\section{論}

本報告では, 超音波凝固切開装置の安全性を検証 する基礎検討として，振動分布の測定と脱気水中で のキャビテーション観察, 発生音圧データの解析を 行った. ブレードの形状，レーザードプラ振動計に よって測定した振動分布とキャビテーション気泡の 発生方向の対応関係が確認出来た，さらに，水中で のブレード周囲の音圧測定，周波数解析から，超音 波凝固切開装置のブレードの大きさと音響出力では, キャビテーションはブレードのごく近傍から局所的 に発生し，気泡は先端が水浸した状況であれば音響 流によって移動するが，機械的作用は発生点近傍に 集中している可能性が高いと考えられる.

今後は，実際の使用状況を考え，液体中でブレー ドと生体組織が接触している状況でのキャビテー ションの影響や，ブレードからのどの程度の距離に 生体組織が存在するとキャビテーションによって損 傷が起きるのかなどを検証する必要がある.

\section{謝辞}

振動分布測定の機器を提供いただき，測定にご協 力いただいた神奈川大学辻野次郎丸名誉教授，上岡 哲宜氏，土屋健伸氏に感謝いたします。ハーモニッ
ク・スカルペルIIを貸与して頂いたジョンソン . アンド・ジョンソン株式会社に感謝いたします。本 研究は日本超音波医学会研究開発班の研究の一環と して行われた。

\section{文献}

1）高島元成, 吉野茂文, 硲彰一, ほ力. 超音波凝固切開 装置. 臨床外科 2006;61(4):431-4.

2）大脇哲洋, 吉中平次, 夏越祥次, ほか. 外科診療に押 ける材料・器具・装置のすべて III装置 超音波凝 固切開装置, 超音波入又. 外科 2005; 67:1549-54.

3） ジョンソン・エンド・ジョンソン. ハーモニックス カルペル II 添付文書 第4 版 (2009)

4）梅村晋一郎. 音響化学効果を利用した癌治療へのア プローチ. 生体医工学 2005;43(2):203-10.

5）梅村晋一郎. 超音波治療と安全性. 超音波テクノ 2004:16(1):22-8.

6）工藤信樹，超音波の安全性について。超音波医学 2008;35(6):623-30.

7) Holland CK,Apfel RE. Thresholds for transient cavitation produced by pulsed ultrasound in a controlled nuclei environment. J Acoust Soc Am 1990;88(5) :205969.

8) Holland CK, Apfel RE. An improved theory for the prediction of microcavitation thresholds, IEEE trans ultrason. ferroelectr. freq. Contr 1989;36(2):204-8.

9) Mason TJ (ed). Sonochemistry: the uses of ultrasound in chemistry. Cambridge, Royal Society of Chemistry; 1990. p. 19.

10）橋本俊介, 岡穂積, 原久裕, ほか. 超音波凝固切開装 置のキャビテーションによる生体傷害作用の解析. 内視鏡外科学会雑誌 2010;15(2):175-81. 